\title{
Recent advances in plastid transformation
}

\author{
Olawole O. Obembe ${ }^{*}$ Jacob O. Popoola, Sadhu Leelavathi ${ }^{1}$ and V. Siva Reddy ${ }^{1}$ \\ Department of Biological Sciences, Covenant University, PMB 1023 Ota, Ogun State, Nigeria. \\ ${ }^{1}$ Plant Transformation Group, International Centre for Genetic Engineering and Biotechnology, Aruna Asaf Ali Marg, \\ New Delhi 110067, India. \\ odun_wole@yahoo.co.uk*
}

\begin{abstract}
Plastid transformation offers a viable alternative to nuclear transformation because of its numerous advantages. It was against this backdrop that various groups of researchers have been exploiting this group of sub-cellular organelles, over the last two decades, for the genetic engineering of agronomic traits and metabolic pathways, as well as for molecular farming for the production of plant-derived high-valued biopharmaceuticals and industrial proteins. In this short review, we discuss the evolution and development of this technology with respect to the current state-of-the-art, which places it in high pedestal as a cost effective and safe production technology for high quality molecular farming products as well as a highly efficient method to create new metabolic pathways and improve the agronomic traits.
\end{abstract}

Keywords: Chloroplast transformation, molecular farming, metabolic engineering, agronomic trait engineering

Evolution and development of plastid transformation

Chloroplasts were considered as endosymbionts derived from ancestral free-living photosynthetic cyanobacteria. However, the genomes of present day land plants encode only about $5-10 \%$ of genes that are present in the cyanobacteria genome, indicating a massive transfer of genome into the nucleus. However, the proteins encoded by the migrated genes come back to plastid for their function through various mechanisms. A comparison of proteins encoded in the Arabidopsis genome with the proteins from the cyanobacterial genomes, suggests that approximately 4,500 of Arabidopsis protein-coding genes ( $18 \%$ of the total) were acquired from the cyanobacterial ancestor of plastids (Martin et al. 2002).

The plastids in higher plants include chloroplasts (green plastids), chromoplasts (yellow or red plastids, found in some fruits and flowers), amyloplasts (containing starch) and elaioplasts (containing oil) (Gillham, 1994). Plastids of higher plants are semi-autonomous organelles with a small circular double stranded DNA with a high copy numbers and have their own transcriptiontranslation machinery. Chloroplast gene expression is regulated at both transcription and translation level and requires a coordinate expression with the nuclear genome. The plastid genome is transcribed by two different RNA polymerases: one encoded by the nucleus (NEP) and the other plastid encoded (PEP). While some plastid genes are transcribed by both NEP and PEP, some are transcribed only by the PEP. While PEP is a prokaryotic-type enzyme, NEP is a T7 RNA polymeraselike enzyme (Hess \& Börner, 1999). There are several sigma factors encoded by the nuclear genome, which are part of the PEP transcription system. The translational apparatus of chloroplasts is similar to that of bacteria, but has adopted to translate mRNAs in the organelle within a eukaryotic cell (Marín-Navarro et al., 2007).

The plastid transformation (PT) technology was birthed as a result of the quest for low cost, safer and more flexible scale-up expression system than the established systems that use bacterial, fungal and animal cells as production platforms for recombinant proteins, especially pharmaceutical proteins. The first stable chloroplast transformation was reported in Chlamydomonas using high velocity microprojectiles by biolistic delivery of naked DNA that integrated into the genome through homologous targeting (Boynton et al., 1988). Although transient foreign gene expression in chloroplasts of cultured tobacco cells after biolistic delivery of chloroplast vectors was reported by Daneill et al. (1990), the first stable plastid transformation in higher land plant was achieved in tobacco by Pal Maliga's group, using same biolistic delivery system (Svab et al., 1990). They used transformation vectors that contain a mutated plastid 16S rRNA ( rrn16) gene that confer spectinomycin and streptomycin resistance. However, a year later, a more efficient selectable marker gene, aadA, encoding aminoglycoside 3'-adenylyltransferase, which inactivate spectinomycin and streptomycin, was discovered (Goldschmidt-Clermont, 1991). This PT marker has since been prominently used for selection of cells containing transformed plastid genomes (ptDNA), even though, an alternative marker, aphA-6, which confers kanamycin resistance, was later found to be of comparable efficiency with aadA (Hunag et al., 2002). Stable plastid transformation in tobacco by an alternate transformation protocol based on polyethylene glycol (PEG) treatment of leaf protoplasts in the presence of plasmid DNA was also reported (Golds et al., 1993). Since the first high-level foreign protein expression of $2.5 \%$ of the total soluble protein was achieved with the bacterial $\beta$-glucuronidase
Review

CIndian Society for Education and Environment (iSee)
"Plastid technology" http://www.indjst.org
O.O. Obembe et al. Indian J.Sci.Technol. 
(GUS), (Staub \& Maliga 1993), there have been significant advances in the development of plastid expression technology, which have largely demonstrated that plastid could indeed serve as a safe platform for the large-scale production of recombinant proteins. Similarly, the first proof of agronomic trait engineering via PT, which was demonstrated by McBride et al. (1995), actually served as the impetus for the advances made in this area of plant biotechnology to date. Additionally, it was around this time that the foundation for the recent advances in the elimination of selectable markers conferring antibiotic resistance, and which are generally of bacterial origin, and as such constitute biosafety concerns, was laid (Carrer \& Maliga, 1995; Fischer et al., 1996). Moreover, the advances made to date with respect to increasing the spectrum of higher plants that are amenable to this technology was premised on the possibility of stably transforming Arabidopsis chloroplasts in 1998 (Sikdar et al., 1998), a feat that doused the notion that the technology may be limited to the Solanaceous species only. The advances in the abovementioned areas of the PT technology, which have now placed it in high pedestal as a cheap and safe production technology for high the preferred stable transformation strategy. These advantages are presented in Table 1. Thus, PT has an unparalleled leverage as a tool for production of valuable compounds through metabolic engineering and molecular farming as well for achieving enhanced efficiency in agronomic trait engineering.

\section{Particle bombardment-mediated transformation}

The gene transfer technique that is generally being used for plastid transformation is the particle bombardment. This can be performed on a wide variety of cell and tissue explants of most species (including nowadays cereal plants), because it is neither speciesnor genotype-dependent, hence it has no biological constraints or host limitation. Besides, this method of transformation can facilitate co-transformation of a cell with two of more transgenes simultaneously (for comprehensive expert review, see Altpeter et al., 2005). The DNA transfer by particle bombardment makes use of physical processes to achieve the transformation of crop plants. The particle bombardment-mediated transformation is performed with a device known as the PDS-1000/He. The device uses high-pressure heliumaided acceleration of gold or tungsten microparticles

Table 1: Advantages of PT over nuclear transformation.

\begin{tabular}{|c|c|}
\hline Plastid transformation & Nuclear transformation \\
\hline $\begin{array}{l}\text { Plastid genome is highly polyploid leading to high accumulation } \\
\text { of protein }\end{array}$ & $\begin{array}{l}\text { Nuclear genome is not highly polyploidy hence low level of } \\
\text { protein expression }\end{array}$ \\
\hline $\begin{array}{l}\text { Plastids possess prokaryotic gene expression system, which } \\
\text { facilitate the expression of several genes simultaneously from } \\
\text { single operons }\end{array}$ & $\begin{array}{l}\text { The nucleus does not possess prokaryotic gene expression } \\
\text { system, hence cannot express several genes simultaneously }\end{array}$ \\
\hline $\begin{array}{l}\text { Facilitates the expression of multi-subunit complex proteins } \\
\text { from polycistronic mRNAs, under a single promoter }\end{array}$ & $\begin{array}{l}\text { The expression of multi-subunit complex proteins from } \\
\text { polycistronic mRNAs is not practicable, hence several promoters } \\
\text { are needed to drive the expressions of the individual genes } \\
\text { encoding the respective subunits }\end{array}$ \\
\hline $\begin{array}{l}\text { Polycistronic multigene expression enables enhanced } \\
\text { sequential metabolic reactions in a single transformation } \\
\text { procedure }\end{array}$ & $\begin{array}{l}\text { Multiple transformation procedure will be required to achieve } \\
\text { multigene expression }\end{array}$ \\
\hline $\begin{array}{l}\text { The use of a single operon to express several genes removes } \\
\text { the burden of using several selection markers }\end{array}$ & $\begin{array}{l}\text { Several selection markers will be used to independently select } \\
\text { for integration events of these individual genes }\end{array}$ \\
\hline $\begin{array}{l}\text { The plastid genome is versatile in codon usage for recombinant } \\
\text { protein production }\end{array}$ & $\begin{array}{l}\text { Widespread codon usage bias exist, hence the codon } \\
\text { optimization is common, in order to optimize translation } \\
\text { efficiency }\end{array}$ \\
\hline $\begin{array}{l}\text { Provides substantial degree of natural biocontainment of } \\
\text { transgene flow by out-crossing, as plastids are inherited through } \\
\text { maternal tissues in most species }\end{array}$ & There is always the risk of out-crossing through pollination \\
\hline $\begin{array}{l}\text { No positional effects and epigenetic interference because } \\
\text { integration is guarded into the functional region of the genome } \\
\text { through homologous targeting. }\end{array}$ & $\begin{array}{l}\text { There are positional effects and epigenetic interference because } \\
\text { integration is random }\end{array}$ \\
\hline Absence of transgene instability and gene silencing & Presence of transgene instability and gene silencing \\
\hline Eliminates the need for transit peptide for the transgene & $\begin{array}{l}\text { transit peptide is needed for genes destined for the plastid } \\
\text { genomes }\end{array}$ \\
\hline
\end{tabular}

Information from Staub et al.( 2000), Maliga (2004), Daniell et al. (2005), Bock (2007), Moeller and Wang (2008), Hasunuma et al. (2008), Cardi et al., 2010, Meyers et al. (2010, Obembe et al. (2010).

quality molecular farming products, and also as a highly coated with DNA. The built-up helium pressure is efficient method for agronomic traits- and metabolic released using a rupture disc, which produces a engineering, are thus the focus of this review paper.

Rationale for the PT technology

The diversely numerous advantages of PT over its nuclear counterpart are the incentive for its adoption as

Review

CIndian Society for Education and Environment (iSee)
"Plastid technology"

http://www.indjst.org shockwave that travels to the second disc (macrocarrier) on which the DNA-coated are spotted. The macrocarrier is then propelled into a stopping screen, which retain the macrocarrier but ensures the continuous travelling of the Indian J.Sci.Technol. 
microprojectiles, which finally hit their target tissues held in a vacuum, facilitating the delivery of the naked DNA into the plant cells and ultimately into the nuclear-, plastid- or mitochondrial genome. Particle bombardment is the most efficient way to achieve plastid transformation in plants and is the only method used to achieve mitochondrial transformation (Maliga \& Small, 2007)

Advances in molecular farming and in the engineering of agronomic traits and metabolic pathways

The application of PT has made tremendous advances in the field of molecular farming for the production of varied high-valued biopharmaceuticals including monoclonal antibody (Daniell et al., 2004), Yand and alpha-interferon (Leelavathi \& Reddy, 2003; Arlen et al., 2007), human alpha 1-antitrypsin (Nadai et al., 2008), insulin-like growth factor (Daniell et al., 2009), and antimicrobial peptide (Oey et al., 2009). Also this platform has been explored for high-level production of a host of vaccine antigens including bacterial antigens such as tetanus and Cholera toxin B (Tregoning et al., 2003; Davoodi-Semiromi et al., 2009) and bio-defense vaccine antigens, anthrax and plaque (Koya et al., 2005; Arlen et al., 2008). Viral antigens including hepatitis C, swine fever virus and human papillomavirus (L1) have also been expressed in the chloroplasts (Birch-Machin et al., 2004; Fernandez-SanMillan et al. 2008; Shao et al. 2008). Other antigens successfully expressed in the chloroplast include the protozoan antigens such as the surface antigen of Entamoeba histolytica and malaria vaccine candidates (Chebolu \& Daniell, 2007; DavoodiSemiromi et al., 2009), and the autoantigens for diabetestype 1, the cholera toxin B-proinsulin fusion protein (CTBpins) and human glutamic acid decarboxylase (hGAD65) (Ruhlman et al., 2007; Wang, X. et al., 2008). Other valuable chloroplast-derived products include elastinderived polymer and monellin (Guda et al., 2000; Roh et al., 2006).

With respect to metabolic engineering, the PT platform has made remarkable advances in increasing the yield of useful compounds such as p-hydroxybenzoic acid ( $25 \%$ dry weight) (which is in hot demand as a major monomer in liquid crystal polymers) (Viitanen et al., 2004) and astaxanthin, which is a highly valued red pigment that is being used as feed supplement in poultry farming and aquaculture (Hasunuma et al., 2008). Additionally, the technology has been used to achieve overproduction of tryptophan, a very important amino acid (Zhang et al., 2001; Tsai et al., 2005) and a polyester, polyhydroxybutyrate (Lössl et al., 2003).

Moreover, several transgenes have conferred useful agronomic traits to the plants including drought resistance (Kumar et al., 2004), bacterial and fungal pathogen resistance (DeGray et al., 2001), herbicide resistance (Ye et al., 2001), and insect resistance (De Cosa et al., 2001; Dufourmantel et al., 2005). Additionally, the TP platform has recently found relevance in bioremediation (Hussein et al., 2007).
Vol. 3 No. 12 (Dec 2010)

ISSN: 0974- 6846

\section{Advances in strategies for enhancing protein expression}

The strategies for enhancing protein expression in the chloroplast have been based on ensuring protein stability rather than transcript abundance due to the lack of correlation between increased transcript level and translation efficiency (Verma \& Daniell, 2007). For example a chaperon for the CRY protein was used to fold an insecticidal protein, Cry2Aa2, into cuboidal crystals, which protected the foreign protein from degradation from chloroplast proteases, thereby leading to remarkable increase in protein accumulation (De Cosa et al., 2001). Similarly, a striking 500-fold increase in expression of the human serum albumin was achieved when regulated in the light for protection inside inclusion bodies (Fernandez-San Millan et al., 2003). Also, some proteins such as insulin are unstable in the chloroplast; as such can only gain stability when expressed as fusion proteins. For example the fusion of insulin with Cholera toxin Bsubunit led to high expression of up to $16 \%$ of the total soluble protein (Ruhlman et al., 2007). Additionally, codon optimization has also been recently found to enhance protein expression, to a certain extent, in the chloroplasts (Zhou et al., 2008; Oey et al., 2009).

Besides, Oey et al. (2009) were able to accumulate a phage-derived bactericidal protein to an unprecedented level of over $70 \%$ of the plant's total soluble protein (the highest foreign protein expression level obtained in plant so far). They exploited the evolutionary resistance of phage lysins against prokaryotic proteases for achieving a very high stability of the protein inside the chloroplasts, which retain prokaryotic gene-expression machinery. This unrivalled foreign protein expression further validates the PT technology as an expression platform for costeffective large-scale production of proteinaceous pharmaceuticals. It is also worthy of note that the protein antibiotic killed the pathogenic group A streptococci without any purification, an advantage that is especially relevant when the protein antibiotic is to be produced for topical application (Oey et al., 2009).

\section{Advances in marker excision strategies}

The main reason for the clamor for the removal of the maker genes from transgenic plants is because of the antibiotic resistance they confer, which poses appreciable biosafety concerns. Besides, their presence will no longer be necessary to maintain the transplastomic state when plants with a uniformly transformed ptDNA population have been obtained, as such their removal will spare the transgenic plant of the unnecessary metabolic burden imposed by high-level expression of the marker gene (Lutz \& Maliga, 2007). Four strategies being used for plastid marker gene excision include homology-based excision through directly repeated sequences, excision by phage site-specific recombination system, transient cointegration of the marker gene and the cotransformation-segregation approach.

The homology-based excision through directly repeated sequences relies on loop-out elimination of
Review

CIndian Society for Education and Environment (iSee)
"Plastid technology"

http://www.indjst.org
O.O. Obembe et al. Indian J.Sci.Technol. 
sequence between two directly oriented repeats. There have been a lot of advances since the first demonstrations of this approach in tobacco and Chlymadomonas in the mid 90s (Carrer \& Maliga, 1995; Fischer et al., 1996). These include the interruption of an herbicide resistance gene with excisable selectable marker, such that after marker elimination, the integrity of the herbicide resistance gene can be restored and as such can be used for identifying the marker-free clones (Dufourmantel et al., 2007). The second advance is the visual identification of the marker-free plants as a result of a loss of function of a co-excised plastid pigmentation gene, $r b c l$ (Kode et al., 2006).

However, a second more efficient and widely adopted strategy for marker gene excision is the use of the nuclear-encoded, plastid targeted phage site-specific recombinases. This involves the construction of transplastomic plants, which carry a marker gene flanked by two directly oriented recombinase target sites. The marker gene is then removed by the introduction of a gene encoding a plastid-targeted recombinase in the plant nucleus, which eventually enters all plastids and simultaneously excises the marker genes flanked by directly oriented target sites (Lutz \& Maliga, 2007). Two of such recombinases, the Cre recombinase, derives from the P1 bacteriophage, and which excises target sequences flanked by directly oriented 34 bp loxP sites (Corneille et al., 2001; Kuroda \& Maliga, 2003, Tungsuchat et al., 2006; Sinagawa-García et al., 2009; Zhou et al., 2008) and the ФC31 phage integrase, Int (Lutz et al., 2004; Kittiwongwattana et al., 2007) have been used successfully to achieve marker-free transplastomic plants.

The transient co-integration approach is more effortdemanding and consequently enjoys less adoption. This is because the removal of the selectable marker gene involves the generation of a loss of function mutant lines generated by knocking down the photosynthetic gene rpoA or petA and a subsequent gene complementation for the restoration of the lost green pigmentation capability (Klaus et al., 2003; 2004).

The co-transformation-segregation approach relies on co-transformation and segregation of the ptDNA that has been transformed independently with two plasmids, a marker gene and an herbicide resistance gene. The transplastomic clones are identified by selection for spectinomycin resistance, with the resultant heteroplastomic cell carrying the wild-type ptDNA, the ptDNA with marker gene integration, the ptDNA with herbicide gene integration and the ptDNA with both vectors. Subsequent replication and segregation of the ptDNA on non-selective medium eventually yields chloroplasts with homoplastomic ptDNA for both vectors as well as for the single individual vectors. As high as $20 \%$ of the desired herbicide-resistant plants, which lack the antibiotic resistance marker was obtained for tobacco (Ye et al., 2003).
A recent and promising alternative approach that has been developed for tobacco plastid transformation involves the use of a selection system that is based on the feedback-insensitive anthranilate synathase (AS) $\alpha$ subunit of tobacco (ASA2) as a new selective marker and the indole analogue 4-methylindole (4MI) or the tryptophan analogue 7-methyl-DL-tryptophan (7MT) as the selection agents (Barone et al., 2009).

\section{Advances in widening the range of crop species}

Even though tobacco proffers almost infinite advantages as an ideal crop for various applications of the PT, however, the presence of nicotine and other alkaloids has been the single major disadvantage, especially for the production of biopharmaceuticals, the recent use of low-nicotine varieties like LAMD (Arlen et al., 2007) not withstanding (Verma \& Daniell, 2007). The need to broaden the crop spectrum for PT is particularly imperative for oral delivery systems. It is therefore exciting to note that the range of the PT-amenable crops has been broadened since the first stable plastid transformation was achieved in a non-tobacco species in 1998 (Sikdar et al., 1998). As such, stable PT has been successfully achieved in crops species such as oilseed rape (Hou et al., 2003), petunia (Zubko et al., 2004) and poplar (Okumura et al., 2006), following the same protocols developed for tobacco, with minor modifications though. It is even more excitingly noteworthy that chloroplast transformation has been possible in leafy edible crops like lettuce and cabbage (Kanamoto et al., 2006; Liu et al., 2007), and other edible crops like potato (Nguyen et al., 2005), tomato (Ruf et al., 2001), and carrot (Kumar et al., 2004a), which offer ideal systems for the oral delivery platform. The range of PT-amenable crops has even been widen to include also the economically important crops such as cotton (Kumar et al., 2004b), rice (Lee et al., 2006) and soybean (Dufourmantel et al., 2004). Not only is the PT technology available for these variety of crop species but also that it employs different plant regeneration approaches including somatic embryogenesis and organogenesis from leaf and protoplast cultures, which makes it all the more promising to still increase the crop species base for the technology.

\section{Future prospects}

So far plastid transformation has been accomplished in relatively few species. There are several factors that have limited the expansion of plastid transformation technology to agronomically more important crop species such as cereal crops. A major factor is the lack of good selection marker that can be used in rice, wheat, maize etc. Also lack of reproducible tissue culture procedures that are compatible to plastid transformation is another serious limiting factor. Although some partial success was achieved in rice, generating a homoplastomic lines remained a distant dream. Moreover, it is not possible to generate homoplastomic plants via subsequent rounds of regeneration using leaves as explants. Based on the
Review

CIndian Society for Education and Environment (iSee)
"Plastid technology"

http://www.indjst.org
O.O. Obembe et al. Indian J.Sci.Technol. 
knowledge available, it is possible in the near future to apply plastid transformation to improve the agronomic traits in important crop species. Nevertheless, the available plastid transformation and expression technology in several dicots can be readily exploited for the large scale production of high value products required in bulk quantities useful in human health and technical industry.

\section{Acknowledgement}

Olawole O. Obembe would like to thank the International Centre for Genetic Engineering and Biotechnology (ICGEB), Trieste, Italy for sponsoring his Post-doctoral training on Chloroplast Engineering at the Plant Transformation Laboratory of ICGEB, New Delhi Component, India. $\mathrm{He}$ is also indebted to the Management of the Covenant University, Ota Nigeria, for granting him study leave during the training period.

\section{References}

1. Altpeter $\mathrm{F}$, Baisakh $\mathrm{N}$, Beachy $\mathrm{R}$, Bock $\mathrm{R}$, Capell T, Christou P, Daniell H, Datta K, Datta S, Dix PJ, Fauquet C, Huang N, Kohli A, Mooibroek $\mathrm{H}$, Nicholson L, Nguyen TT, Nugent G, Raemakers $\mathrm{K}$, Romano A, Somers DA, Stoger E, Taylor N and Visser RGF (2005) Particle bombardment and the genetic enhancement of crops: myths and realities. Mol. Breed. $15,305-327$.

2. Arlen PA, Falconer R, Cherukumilli S, Cole A, Cole AM, Oishi KK and Daniell H (2007) Field production and functional evaluation of chloroplast derived interferona2b. Plant Biotechnol. J. 5, 511-525.

3. Arlen PA, Singleton M, Adamovicz JJ, Ding Y, DavoodiSemiromi A and Daniell H (2008) Effective plague vaccination via oral delivery of plant cells expressing $\mathrm{F} 1$ $\checkmark$ antigens in chloroplasts. Infect. Immun. 76, 3640-3650.

4. Barone $\mathrm{P}$, Zhang X-H and Widholm JM (2009) Tobacco plastid transformation using the feedback insensitive anthranilate synthase [a]-subunit of tobacco (ASA2) as a new selectable marker. J. Exp. Bot. 60, 3195-3202.

5. Birch-Machin I, Newell CA, Hibberd JM and Gray JC (2004) Accumulation of rotavirus VP6 protein in chloroplasts of transplastomic tobacco is limited by protein stability. Plant Biotechnol. J. 2, 261-270.

6. Bock R (2007) Plastid biotechnology: Prospects for herbicide and insect resistance, metabolic engineering, and molecular farming. Curr. Opin. Biotechnol. 18, 100106.

7. Boynton JE, Gillham NW, Harris EH, Hosler JP, Johnson $A M$, Jones AR, Randolph-Anderson BL, Robertson D, Klein TM, Shark KB and Sanford JC (1988) Chloroplast transformation in Chlamydomonas with high velocity microprojectiles. Science. 240, 1534-1538.

8. Cardi T, Lenzi P and Maliga P (2010) Chloroplasts as expression platform for plant-produced vaccines. Expert Rev. Vaccin. 9, 893-911.

9. Carrer H and Maliga P (1995) Targeted insertion of foreign genes into the tobacco plastid genome without physical linkage to the selectable marker gene. Biotechnol. 13, 791-794.
10.Chebolu S and Daniell H (2007) Stable expression of Gal/GalNAc lectin of Entamoeba histolytica in transgenic chloroplasts and immunogenicity in mice towards vaccine development for amoebiasis. Plant Biotechnol. J. 5, 230239.

11.Corneille S, Lutz K, Svab Z and Maliga P (2001) Efficient elimination of selectable marker genes from the plastid genome by the CRE-lox sitespecific recombination system. Plant J. 27, 171-178.

12.Daniell H, Carmona-Sanchez $O$ and Burns B (2004) Chloroplast derived antibodies, biopharmaceuticals and edible vaccines. In: Molecular Farming. Fischer R \& Schillberg S (Eds.) Verlag Publ., Weinheim, Germany. pp: 113-133.

13. Daniell $H$, Chebolu S, Kumar $S$, Singleton $M$ and Falconer R (2005) Chloroplast-derived vaccine antigens and other therapeutic proteins. Vaccine. 23, 1779-1783.

14.Daniell $H$, Uiz G, Denes $B$, Sandberg $L$ and Langridge $W$ (2009) Optimization of codon composition and regulatory elements for expression of human insulin like growth factor-1 in transgenic chloroplasts and evaluation of structural identity and function. BMC Biotechnol. 9, 23.

15.Daniell H, Vivekananda J, Nielsen BL, Ye GN, Tewari KK and Sanford JC (1990) Transient foreign gene expression in chloroplasts of cultured tobacco cells after biolistic delivery of chloroplast vectors. Proc. Natl. Acad. Sci. 87, 88-92.

16.Davoodi-Semiromi A, Samson N and Daniell H (2009) The green vaccine: a global strategy to combat infectious and autoimmune diseases. Hum. Vaccin. 5, 488-493.

17.De Cosa B, MoarW, Lee SB, Miller $M$ and Daniell $H$ (2001) Overexpression of the $\mathrm{Bt}$ cry2Aa2 operon in chloroplasts leads to formation of insecticidal crystals. Nat. Biotechnol. 19, 71-74.

18.DeGray G, Rajasekaran K, Smith F, Sanford J and Daniell H (2001) Expression of an antimicrobial peptide via the chloroplast genome to control phytopathogenic bacteria and fungi. Plant Physiol. 127, 852-862.

19.Dufourmantel $N$, Dubald $M$, Matringe $M$, Canard $H$, Garcon F, Job C, Kay E, Wisniewski JP, Ferullo JM, Pelissier B, Sailland A and Tissot G (2007) Generation and characterization of soybean and marker-free tobacco plastid transformants over-expressing a bacterial 4hydroxyphenylpyruvate dioxygenase which provides strong herbicide tolerance. Plant Biotechnol. J. 5, 118133.

20.Dufourmantel N, Pelissier B, Garcxon F, Peltier G, Ferullo JM and Tissot G (2004) Generation of fertile transplastomic soybean. Plant Mol. Biol. 55, 479-489.

21.Dufourmantel N, Tissot G, Goutorbe F, Garcxon F, Muhr C, Jansens S, Pelissier B, Peltier G and Dubald M (2005) Generation and analysis of soybean plastid transformants expressing Bacillus thuringiensis Cry $1 \mathrm{Ab}$ protoxin. Plant Mol. Biol. 58, 659-668.

22.Fernandez-San Millan A, Mingo-Castel $A$, Miller $M$ and Daniell H (2003) A chloroplast transgenic approach to hyper-express and purify human serum albumin, a protein highly susceptible to proteolytic degradation. Plant Biotechnol. J. 1, 71-79.
"Plastid technology" http://www.indjst.org
O.O.Obembe et al. Indian J.Sci.Technol. 
23.Fernandez-SanMillan A, Ortigosa SM, Hervás-Stubbs S, Corral-Martínez P, Seguí-Simarro JM, Gaétan J, Coursaget $P$ and Veramendi $J$ (2008) Human papillomavirusL1 protein expressed in tobacco chloroplasts self-assembles into virus-like particles that are highly immunogenic. Plant Biotechnol. J. 6, 427-441.

24.Fischer NO, Stampacchia K and Redding RJ-D (1996) Selectable marker recycling in the chloroplast. Mol. Gen. Genet. 251, 373-380.

25. Gillham NW (1994) Organelle genes and genomes. Oxford University Press, NY.

26. Golds T, Maliga P and Koop HU (1993) Stable plastid transformation in PEG-treated protoplasts of Nicotiana tabacum. Bio. Technol. 11, 95-97.

27.Goldschmidt-Clermont M (1991) Transgenic expression of aminoglycoside adenine transferase in the chloroplast: a selectable marker of site-directed transformation of chlamydomonas. Nucleic Acids Res. 19, 4083-4089.

28. Guda C, Lee SB and Daniell H (2000) Stable expression of a biodegradable protein-based polymer in tobacco chloroplasts. Plant Cell Rep. 19, 257-262.

29. Hasunuma T, Miyazawa S, Yoshimura S, Shinzaki Y, Tomizawa K, Shindo K, Choi S, Misawa N and Miyake C (2008) Biosynthesis of astaxanthin in tobacco leaves by transplastomic engineering. Plant J. 55, 857-868.

30. Hasunuma T, Miyazawa S, Yoshimura S, Shinzaki Y, Tomizawa K-I, Shindo K, Choi S-K, Misawa N and Miyake C (2008) Biosynthesis of astaxanthin in tobacco leaves by transplastomic engineering. Plant J. 55, 857868.

31. Hess WR and Börner T (1999) Organellar RNA polymerases of higher plants. Int. Rev. Cytol. 190,1-59.

32. Hou BK, Zhou YH, Wan LH, Zhang ZL, Shen GF, Chen $\mathrm{ZH}$ and $\mathrm{Hu} \mathrm{ZM}$ (2003) Chloroplast transformation in oilseed rape. Transgenic Res. 12, 111-114.

33. Hunag FC, Klaus SMJ, Herz S, Zou Z, Koop H-U and Golds TJ (2002) Efficient plastid transformation in tobacco using the aphA-6 gene and kanamycin selection. Mol. Genet. Genom. 268, 19-27.

34. Hussein SH, Ruiz ON, Terry N and Daniell H (2007) Phytoremediation of mercury and organomercurials in chloroplast transgenic plants: enhanced root uptake, translocation to shoots and volatilization. Environ. Sci. Technol. 41, 8439-46.

35. Kanamoto H, Yamashita A, Asao H, Okumura S, Takase H, Hattori M, Yokota A and Tomizawa K (2006) Efficient and stable transformation of Lactuca sativa L. Cv. Cisco (lettuce) plastids. Transgenic Res. 15, 205-217.

36. Kittiwongwattana $C$, Lutz KA, Clark $M$ and Maliga $P$ (2007) Plastid marker gene excision by the phiC31 phage site-specific recombinase. Plant Mol. Biol. 64, 137-143.

37.Klaus SMJ, Huang FC, Eibl C, Koop HU and Golds TJ (2003) Rapid and proven production of transplastomic tobacco plants by restoration of pigmentation and photosynthesis. Plant J. 35, 811-821.

38. Klaus SMJ, Huang FC, Golds TJ and Koop H-U (2004) Generation of marker-free plastid transformants using a transiently cointegrated selection gene. Nat. Biotechnol. 22, 225-229.
Vol. 3 No. 12 (Dec 2010)

ISSN: 0974- 6846
39.Kode V, Mudd E, lamtham S and Day A ( 2006) Isolation of precise plastid deletion mutants by homology-based excision: a resource for site-directed mutagenesis, multigene changes and high-throughput plastid transformation. Plant J. 46, 901-909.

40.Koya V, Moayeri M, Leppla SH and Daniell H (2005) Plant-based vaccine: mice immunized with chloroplastderived anthrax protective antigen survive anthrax lethal toxin challenge. Infect. Immun. 73, 8266-8274.

41.Kumar S, Dhingra A and Daniell H (2004a) Plastidexpressed betaine aldehyde dehydrogenase gene in carrot cultured cells, roots, and leaves, confers enhanced salt tolerance. Plant Physiol. 136, 2843-2854.

42. Kumar S, Dhingra A and Daniell H (2004b) Stable transformation of the cotton plastid genome and maternal inheritance of transgenes. Plant Mol. Biol. 56, 203-216.

43. Kuroda H and Maliga P (2003) The plastid clpP1 gene is essential for plant development. Nature. 425, 86-89.

44.Lee SM, Kang K, Chung H, Yoo SH, Xu XM, Lee SB, Cheong JJ, Daniell H and Kim M (2006) Plastid transformation in the monocotyledonous cereal crop, rice (Oryza sativa) and transmission of transgenes to their progeny. Mol. Cells. 21, 401-410.

45.Liu CW, Lin CC, Chen J and Tseng MJ (2007) Stable chloroplast transformation in cabbage (Brassica oleracea var. capitata L.) by particle bombardment. Plant Cell. Rep. 26, 1733-1744.

46. Lössl A, Eibl C, HarloffHJ, Jung C and Koop HU (2003) Polyester synthesis in transplastomic tobacco (Nicotiana tabacum L.): significant contents of polyhydroxybutyrate are associated with growth reduction. Plant Cell. Rep. 21, 891-899.

47.Lutz K, Corneille S, Azhagiri AK, Svab Z and Maliga P (2004) A novel approach to plastid transformation utilizes the phiC31 phage integrase. Plant J. 37, 906-913.

48. Lutz KA and Maliga P (2007) Construction of marker-free transplastomic plants. Curr. Opin. Biotechnol. 18, 107114.

49. Maliga P (2004) Plastid transformation in higher plants. Ann Rev. Plant Biol. 55, 289-313.

50. Maliga P and Small I (2007) Plant biotechnology 2007: all three genomes make contributions to progress. Curr. Opin. Biotechnol. 18, 97-99.

51. Marín-Navarro1 J, Manuell AL, Wu J and Mayfield SP (2007) Chloroplast translation regulation. Photosynthesis Res. 94, 359-374.

52. Martin W, Rujan T, Richly E, Hansen A, Cornelsen S, Lins T, Leister D, Stoebe B, Hasegawa M and Penny D (2002) Evolutionary analysis of Arabidopsis, cyanobacterial, and chloroplast genomes reveals plastid phylogeny and thousands of cyanobacterial genes in the nucleus. Proc. Natl. Acad. Sci. 99, 12246-12251.

53.McBride KE, Svab Z, Schaaf DJ, Hogan PS, Stalker DM and Maliga P. (1995) Amplification of a chimeric Bacillus gene in chloroplasts leads to an extraordinary level of an insecticidal protein in tobacco. Biotechnol. 13, 362-365.

54. Meyers B, Zaltsman A, Lacroix B, Kozlovsky SV and Krichevsky A (2010) Nuclear and plastid genetic engineering of plants: Comparison of opportunities and challenges. Biotechnol. Adv. 6, 747-756.
Review

CIndian Society for Education and Environment (iSee)
"Plastid technology"

http://www.indjst.org
O.O. Obembe et al. Indian J.Sci.Technol. 
55.Moeller L and Wang K (2008) Engineering with Precision: Tools for the New Generation of Transgenic Crops. BioScience. 58, 391-401.

56. Nadai M, Bally J, Vitel M, Job C, Tissot G, Botterman J and Dubald M (2008) High-level expression of active human alpha1- antitrypsin in transgenic tobacco chloroplasts. Transgenic Res. 18,173-183.

57.Nguyen TT, Nugent G, Cardi T and Dix PJ (2005) Generation of homoplasmic plastid transformants of a commercial cultivar of potato (Solanum tuberosum L.). Plant Sci. 168, 1495-1500.

58. Obembe OO, Popoola JO, Leelavathi S and Reddy VS (2010) Advances in Plant Molecular Farming. Biotechnol. Adv. doi:10.1016/j.biotechadv.2010.11.004.

59. Oey M, Lohse M, Scharff LB, Kreikemeyer B and Bock R (2009) Plastid production of protein antibiotics against pneumonia via a new strategy for high-level expression of antimicrobial proteins. Proc. Natl. Acad. Sci. USA. 106, 6579-6584.

60. Okumura S, Sawada M, Park YW, Hayashi T, Shimamura $\mathrm{M}$, Takase $\mathrm{H}$ and Tomizawa $\mathrm{K}$ (2006) Transformation of poplar (Populus alba) plastids and expression of foreign proteins in tree chloroplasts. Transgenic Res. 15, 637646.

61.Roh KH, Shin KS, Lee YH, Seo SC, Park HG, Daniell H and Lee SB (2006). Accumulation of sweet protein monellin is regulated by the psbA $5^{\prime}$ UTR in tobacco chloroplasts. J. Plant Biol. 49, 34-43.

62.Ruf S, Hermann M, Berger IJ, Carrer $\mathrm{H}$ and Bock R (2001) Stable genetic transformation of tomato plastids and expression of a foreign protein in fruit. Nat. Biotechnol. 19, 870-875.

63.Ruhlman $T$, Ahangari $R$, Devine $A$, Samsam $M$ and Daniell H (2007) Expression of cholera toxin B-proinsulin fusion protein in lettuce and tobacco chloroplasts - oral administration protects against development of insulitis in non-obese diabetic mice. Plant Biotechnol. J. 5, 495-510.

64.Sadhu L and Reddy VR (2003) Chloroplast expression of His-tagged GUS-fusions: a general strategy to overproduce and purify foreign proteins using transplastomic plants as bioreactors. Mol. Breed. 11, 4958.

65.Shao HB, He DM, Qian KX, Shen GF and Su ZL (2008) The expression of classical swine fever virus structural protein E2 gene in tobacco chloroplasts for applying chloroplasts as bioreactors. C. R. Biol. 331, 179-184.

66.Sikdar SR, Serino G, Chaudhuri S and, Maliga P (1998) Plastid transformation in Arabidopsis thaliana. Plant Cell Rep. 18, 20-24.

67.Sinagawa-García SR, Tungsuchat-Huang T, ParedesLópez O and Maliga P (2009) Next generation synthetic vectors for transformation of the plastid genome of higher plants. Plant Mol. Biol. 70, 487-498.

68.Staub JM, Garcia B, Graves J, Hajdukiewicz PTJ, Hunter P, Nehra N, Paradkar V, Schlittler M, Carroll JA, Spatola L, Ward D, Ye G and Russell DA (2000) High-yield production of a human therapeutic protein in tobacco chloroplasts. Nat. Biotechnol. 18, 333-338.

69.Staub, J.M. and Maliga, P. (1993) Accumulation of D1 polypeptide in tobacco plastids is regulated via the untranslated region of the psbA mRNA. EMBO J. 12, 601-60.

70.Svab Z, Hajdukiewicz P and Maliga P (1990) Stable transformation of plastids in higher plants. Proc. Natl. Acad. Sci. USA. 87, 8526-8530.

71. Tregoning JS, Nixon P, Kuroda H, Svab Z, Clare S, Bowe F, Fairweather N, Ytterberg J, van Wijk KJ, Dougan G and Maliga P (2003) Expression of tetanus toxin Fragment C in tobacco chloroplasts. Nucleic Acids Res. 31, 1174-1179.

72.Tsai FY, Brotherton JE and Widholm JM (2005) Overexpression of the feedback-insensitive anthranilate synthase gene in tobacco causes tryptophan accumulation. Plant Cell Rep. 23, 548-556.

73. Tungsuchat $T$, Kuroda $H$, Narangajavana $J$ and Maliga $P$ (2006) Gene activation in plastids by the CRE sitespecific recombinase. Plant Mol. Biol. 61, 711-718.

74. Verma D and Daniell H (2007) Chloroplast vector systems for biotechnology applications. Plant Physiol. $145,1129-1143$.

75.Viitanen PV, Devine AL, Khan MS, Deuel DL, Van Dyk DE and Daniell H (2004) Metabolic engineering of the chloroplast genome using the Escherichia coli ubiC gene reveals that chorismate is a readily abundant plant precursor for p-hydroxybenzoic acid biosynthesis. Plant Physiol. 136, 4048-4060.

76. Wang X, Brandsma M, Tremblay R, Maxwell D, Jevnikar $\mathrm{AM}$, Huner $\mathrm{N}$ and $\mathrm{Ma} S$ (2008) A novel expression platform for the production of diabetes-associated autoantigen human glutamic acid decarboxylase (hGAD65). BMC Biotechnol. 8, 87.

77. Ye GN, Colburn SM, Xu CW, Hajdukiewicz PTJ and Staub JM (2003) Persistence of unselected transgenic DNA during a plastid transformation and segregation approach to herbicide resistance. Plant Physiol. 133, 402410.

78.Ye G-N, Hajdukiewicz PTJ, Broyles D, Rodriguez D, Xu CW, Nehra N and Staub JM (2001) Plastid-expressed 5enolpyruvylshikimate- 3-phosphate synthase genes provide high level glyphosate tolerance in tobacco. Plant J. 25, 261-270.

79.Zhang $\mathrm{XH}$, Brotherton JE, Widholm JM and Portis AR Jr. (2001). Targeting a nuclear antheranilate synthase a subunit gene to the tobacco plastid genome results in enhanced tryptophan biosynthesis. Return of a gene to its pre-endosymbiotic origin. Plant Physiol. 127, 131-141.

80.Zhou F, Badillo-Corona JA, Karcher D, Gonzalez-Rabade N, Piepenburg K, Borchers A-MI, Maloney AP, Kavanagh TA, Gray JC and Bock R (2008) High-level expression of human immunodeficiency virus antigens from the tobacco and tomato plastid genomes. Plant Biotechnol. J. 6, 897913.

81.Zubko M, Zubko E, Zuilen K, Meyer P and Day A (2004) Stable transformation of petunia plastids. Transgenic Res. 13, 523-530.
"Plastid technology" http://www.indjst.org
O.O.Obembe et al. Indian J.Sci.Technol. 